\title{
Genetic modification of fibre digestion
}

\author{
BY HARRY J. GILBERT \\ Department of Agricultural Biochemistry and Nutrition, University of Newcastle upon Tyne, \\ Newcastle upon Tyne NE1 7RU \\ AND GEOFFREY P. HAZLEWOOD \\ Department of Biochemistry, AFRC Institute of Animal Physiology and Genetics Research, \\ Babraham, Cambridge CB2 4AT
}

Plant biomass is an extensive renewable resource which already plays a central role in herbivore nutrition, but has the further potential to serve as a raw material for industrial processes leading to the production of bulk organics, fine chemicals and biofuel. Microbial enzymes which reside in the gut of both ruminant and non-ruminant herbivores and degrade plant structural polysaccharides, represent the means by which most of the energy and carbon contained in plant biomass may be released. Such enzymes have been the subject of much biochemical research, but since the advent of recombinant DNA (rDNA) technology during the late 1970s, various research groups have, in addition, focused on molecular aspects of these enzymes, and in particular on the introduction of cellulose-degrading capacity into non-cellulolytic organisms by techniques known broadly as genetic engineering.

The major components of plant cell walls are hemicellulose, cellulose and lignin (Demeyer, 1981). Cellulose, the linear $\beta 1 \rightarrow 4$ homopolymer of glucose forms tightly packed parallel molecules linked together by hydrogen bonds. The resulting fibrils are embedded in a ligno-hemicellulose complex. The most abundant hemicelluloses are branched chain $\beta 1 \rightarrow 4$ xylans and glucomannan which are covalently bound to lignin, an heterogeneous phenolic polymer (Whistler \& Richards, 1970). Pectin, which is an $\alpha 1 \rightarrow$ 4 polymer of galacturonic acid, is a minor component of grass cell walls.

To realize the full potential of plant biomass in animal nutrition requires an efficient system for the complete enzymic hydrolysis of plant structural polysaccharides into their constituent monomers. The weighty problem of improving the effectiveness of naturallyoccurring cellulolytic micro-organisms or introducing plant-cell-wall hydrolysing capacity into non-cellulolytic organisms, has two main aspects. First, the analysis of enzymes which hydrolyse plant cell walls and the genes which encode them. This will facilitate the future construction of novel genes, encoding multi-functional hybrid enzymes with enhanced activity against cellulose and hemicellulose. Second, the development of host-vector systems which will enable the genes developed in the first phase to be efficiently expressed in organisms that would then be used to elicit improved fibre utilization by both ruminants and non-ruminants.

\section{ANALYSIS OF PLANT-FIBRE-DEGRADING ENZYMES}

Fungal cellulases. Cellulose is hydrolysed by the synergistic action of a number of different enzymes. In fungi these enzymes are defined as exo-1,4- $\beta$-glucanases (cellobiohydrolases), endo-1,4- $\beta$-glucanases and $\beta$-glucosidases (Wood, 1989). Cellulases synthesized by Trichoderma reesei have been extensively studied. At the molecular level, 
the enzymes consist of two distinct functional domains; a cellulose-binding domain (CBD) and a catalytic domain (CD). These domains are linked by short sequences rich in hydroxy O-glycosylated amino acids (Teeri et al. 1987; Tomme et al. 1988). Typical of fungal cellulolytic systems, $T$. reesei expresses multiple (Van Tilbeurgh et al. 1986; Tomme et al. 1988) endoglucanases (EG) and cellobiohydrolases (CBH). The role of the $\mathrm{CBD}$ in these enzymes has received considerable attention. Tomme et al. (1988) showed that removal of the CBD from CBHI of $T$. reesei greatly reduced the enzyme's capacity to bind and hydrolyse crystalline cellulose, although it still digested amorphous and soluble cellulose efficiently. Knowles et al. (1988) argued that these findings showed that the $\mathrm{CBD}$ of $\mathrm{CBH}$ disrupts the $\mathrm{H}$ bonding between cellulose fibrils and consequently allows the $C D$ to hydrolyse the $\beta-1,4$-bonds. Many fungal cellulases retain catalytic activity after proteolysis. Indeed, Eriksson \& Pettersson (1982) report that Sporotrichum pulverulentum proteases activate the organism's EG. Knowles et al. (1988) suggested that cleavage of the $\mathrm{CBD}$ of EG may play an important role in altering substrate specificity dependent on the nature of the cellulosic molecules present. Thus, the fungus can increase the range of substrate specificities of existing enzymes without increasing the number of cellulase genes.

It is generally agreed that synergism between endoglucanases and exoglucanases during cellulose hydrolysis is apparent when crystalline cellulose is the substrate, but is less significant when the enzymes are cleaving amorphous or soluble forms of the polysaccharide (Wood, 1989). This synergism is not restricted to enzymes from the same organism, but occurs between EG and $\mathrm{CBH}$ from different cellulolytic fungi (Wood et al. 1988).

Recently, the molecular biology of fungal cellulases has received considerable attention. Much of the work has focused on the $T$. reesei system. To date, four cellulase genes from this organism have been characterized: two $\mathrm{CBH}, \mathrm{CBHI}$ (Shoemaker et al. 1983) and CBHII (Chen et al. 1987; Teeri et al. 1987), and two EG, EGI (Penttila et al. 1986) and EGIII (Saloheimo et al. 1988). The genes coding for CBHI and EGI are derived from a common gene and show respectively $50 \%$ and $45 \%$ nucleotide and amino acid homology. In contrast CBHII and EGIII show very little similarity either with each other or with other $T$. reesei cellulases. The thirty-five amino acid sequence at the $\mathrm{N}-(\mathrm{CBHII}, \mathrm{EGIII})$, and C-(CBHI, EGI) termini of these enzymes are $70 \%$ conserved and constitute the CBD. The four genes analysed contain short introns typical of filamentous fungal genes (Knowles et al. 1988). In two genes (CBHII, EGI) the introns are located near the hydroxy amino acid linker sequence, supporting the idea that fungal cellulases have been assembled by exon-shuffling.

Recent studies have shown that $T$. reesei EG and CBH (Penttila et al. 1987, 1989) can be expressed in heterologous lower eukaryotic hosts. Thus, the feasibility of transferring the cellulolytic system of $T$. reese $i$ to other non-cellulolytic organisms is demonstrated.

Cellulolysis is effected not only by aerobic fungi, but also by the rumen anaerobic fungi Neocallimastix frontalis, Piromonas communis and Sphaeromonas communis (Bauchop, 1981; Orpin, 1984). Each of these organisms produces an extracellular cellulase system that degrades crystalline cellulose. Some strains of $N$. frontalis express cellulases which are even more active than the comparable enzymes from $T$. reesei (Wood, 1989). Although the organism contains EG and $\beta$-glucosidases, evidence for the presence of a $\mathrm{CBH}$ is not definitive. However, when the crude cellulase is heated to $45^{\circ}$ for a prolonged period, the enzyme complex no longer degrades crystalline cellulose, even though EG activity is still apparent. When Trichoderma koningii $\mathrm{CBH}$ is added to the heat-treated 
cellulase the capacity to degrade cotton fibres is restored (Wood et al. 1988). Thus, on balance the evidence suggests that $N$. frontalis does synthesize all three of the enzymes typically found in fungal cellulases and probably secretes them as a high-molecularweight multi-enzyme complex (Lowe et al. 1985).

Bacterial cellulases. The enzymology of bacterial cellulases is less well defined than for corresponding fungal systems. All cellulolytic prokaryotes express multiple cellulases which individually exhibit little activity against crystalline substrates (Béguin, 1990). Exoglucanases have been described in very few cellulolytic bacteria, and only one has been shown to act synergistically with EG to degrade insoluble cellulose (Creuzet $e$ al . 1983). The structural organization of bacterial cellulases is variable. In aerobic soil organisms such as Pseudomonas fluorescens ssp. cellulosa and Cellulomonas fimi, cellulases do not associate into large multi-enzyme complexes. In contrast, many anaerobic bacteria, such as Clostridium thermocellum and those which reside in the rumen, synthesize a cellulase system consisting of a large multi-enzyme complex whose structural organization appears to play a pivotal role in the cellulolysis of crystalline substrate (Lamed \& Bayer, 1988). For example, the cellulase complex of $C$. thermocellum, termed the cellulosome, contains fourteen to eighteen different polypeptides (Lamed et al. 1983). The high affinity of the cellulosome for cellulose is thought to be mediated by an apparently non-catalytic binding factor of $M_{r} 210$ 000-250 000 (Lamed \& Bayer, 1988; Wu et al. 1988). The enzyme system, although active against crystalline cellulose, does not appear to contain a $\mathrm{CBH}$. The molecular architecture of cellulases from aerobic bacteria shows a number of constant features. The enzymes contain two distinct regions, a CD and CBD (Ghangas \& Wilson, 1988; Gilkes et al. 1988; Hall \& Gilbert, 1988; Gilbert et al. 1990), analogous to aerobic fungal cellulases. These functional domains are linked by sequences rich in hydroxy amino acids. Deletion of the CBD does not result in a dramatic decrease in the enzyme's activity against amorphous or crystalline cellulose (Gilkes et al. 1988). Thus, there is some debate as to whether bacterial CBDs play a crucial role in the hydrolysis of crystalline substrates.

In recent years, the molecular biology of bacterial cellulases has also received considerable attention. In excess of forty different prokaryotic cellulase genes have been sequenced and the primary structures of the encoded enzymes deduced (Béguin, 1990). The resultant findings have revealed that multiple cellulases observed in prokaryotes are not the result of post-translational processing of single gene products, but are encoded by multiple genes. The $C$. thermocellum proteins contain a highly conserved twenty-three amino acid repeated sequence which is generally at the C-terminus (Béguin et al. 1989). This reiterated region is not essential for catalytic activity or cellulose binding (Grépinet et al. 1988; Hall et al. 1988; Chauvaux et al. 1989) and, thus, probably plays a key role in the structural organization of the cellulosome. Interestingly, apart from the twenty-three residue sequence, there is little homology between the $C$. thermocellum cellulases indicating that they did not evolve from a single gene. Indeed, apart from Bacillus and Ruminococcus albus enzymes, (Fukumori et al. 1989; Poole et al. 1990) the catalytic domains of multiple cellulases produced by a single organism do not show a high degree of sequence conservation. This argues in favour of isoenzymic cellulases arising from gene tranfer between different bacteria. In contrast, the CBDs of cellulases appear to be highly conserved, suggesting that they might be encoded by a mobile genetic element. Alternatively, because of the relatively short sequences which constitute a CBD (100 amino acids), the scope for divergence of structure is limited. 
It is generally recognized that fungal cellulase systems contain fewer enzymes, although they are more active against insoluble substrates when compared with the bacterial enzymes. This probably reflects the presence of $\mathrm{CBH}$ in the lower eukaryotes, while in prokaryotes exoglucanases are less common and exhibit a low specific activity against crystalline substrates. Why highly active $\mathrm{CBH}$ should be confined to fungi remains an important unresolved question.

Xylanases. Xylan, the most abundant hemicellulose, constitutes up to $35 \%$ of the total dry weight of higher plants. Because of the heterogeneity of xylans, several types of endo- and exo-acting xylanases are required to effect hydrolysis. These include 1,4- $\beta$-Dxylanases, $\beta$-xylosidases, $\alpha$-L-arabinofuranosidases, $\alpha$-glucuronidases, acetyl-xylan esterases and ferulic acid esterases (Wong et al. 1988). Multiple xylanases have been reported in numerous micro-organisms. Five different xylanases have been purified from Aspergillus niger (Takenishi \& Tsujisaka, 1975) and at least three from Clostridium stercorarium (Bérenger et al. 1985), Streptomyces exfoliatus (Sreenath \& Joseph, 1982), Trichoderma sp. (Dekker, 1985) and Penicillium janthinellum (Takenishi \& Tsujisaka, 1973). The underlying reasons for the multiplicity of xylanases remain largely unresolved. For example, xylanase heterogeneity may arise from post-translational modifications such as differential glycosylation and proteolysis, or both. Support for this view is provided by the fact that many xylanases are glycosylated, and can be proteolytically cleaved to produce smaller catalytically active products (Gorbacheva \& Rodionova, 1977). However, recent studies by Gilbert et al. (1988) and Hazlewood et al. (1988) have shown that isoenzymic forms of these enzymes are encoded by multiple genes at least in C. thermocellum and $P$. fluorescens ssp. cellulosa. It is likely that the large number of xylanases in $A$. niger results from a combination of both multiple genes and posttranslational modification. The rationale for expressing multiple xylanases probably resides in the fact that xylosidic linkages in ligno-cellulose are not all equivalent and equally accessible to xylanolytic enzymes (Wong et al. 1988). The presence of true exoxylanases has been demonstrated by Reilly (1981), but these enzymes are not thought to be prevalent among xylanolytic micro-organisms.

Co-operativity between xylanases is a common phenomenon. For example, the maximal rate and degree of hydrolysis of two different xylans, required the action of three distinct xylanases from Trichoderma harzianum (Wong et al. 1988). Similar results were observed for xylanases from Neurospora crassa (Deshpande et al. 1986) and $S$. exfoliatus (Sreenath \& Joseph, 1982). Furthermore, the concerted action of debranching enzymes and endoxylanases increases the rate and the extent of xylan hydrolysis (Lee \& Forsberg, 1987).

Recently, the molecular biology of xylanases has been much studied. Xylanases from C. thermocellum (Grépinet et al. 1988), Bacillus sp. (Paice et al. 1986; Hamamoto et al. 1987), Caldocellum saccharolyticum (Lüthi et al. 1990) and P. fluorescens ssp. cellulosa (Hall et al. 1989) have been cloned and sequenced. The expression of these genes in the non-xylanolytic bacterium Escherichia coli, has enabled the determination of the substrate specificities of these enzymes. The resultant findings confirmed the previously held view that xylanases can either show narrow substrate specificities (Gilbert et al. 1988 ) or are capable of hydrolysing cellulosic substrates in addition to xylan. Recent studies by Ferreira et al. (1990) have shown that xylanase A from $P$. fluorescens ssp. cellulosa contains two distinct functional domains, a CBD, which shows little avidity for xylan, and a CD. Furthermore, Kellett et al. (1990) have demonstrated that a second 
xylanase and an arabinofuranosidase, synthesized by the pseudomonad, exhibit the same molecular architecture as xylanase $\mathrm{A}$. The chromosomal location of xylanase and cellulase genes has also been investigated. In $P$. fluorescens ssp. cellulosa xynA and celA (Hall \& Gilbert, 1988; Hall et al. 1989) are adjacent on the chromosome as are the $x y n B$ and $x y n C$ genes. The CBD and serine-rich linker sequences of the pseudomonad cellulases and xylanases show a high degree of sequence conservation (Hall \& Gilbert, 1988; Hall et al. 1989; Gilbert et al. 1990) which is particularly pronounced in XYLB and XYLC, where the first 300 residues of the mature proteins show complete identity (Kellett et al. 1990). Other examples of close linkage of cellulases and xylanases include two homologous EG genes from Bacillus sp. strain N-4 (Fukumori et al. 1986), celX and celE of C. thermocellum (Hall et al. 1988), xynA (xylanase) and xynC (xylan esterase) of C. saccharolyticum (Lüthi et al. 1990). However, apart from these examples, cellulase and xylanase genes are not clustered on bacterial or fungal genomes.

\section{IMPROVING THE ACTIVITY OF CELLULASES AND XYLANASES}

The major limitation in cellulolysis is the very low specific activity of cellulases and xylanases when acting on native substrates such as plant cell walls. The understanding of the molecular architecture, and the mechanisms by which functional domains of the proteins contribute to enzyme action, is required before the primary structure of these enzymes can be modified to elicit an improvement in catalytic activity. Particularly important questions which must be resolved are: (1) What, if any, is the contribution of fungal and bacterial CBD to the hydrolysis of cellulose? (2) What is the role of the CBD in xylanase action? (3) What is the minimum number of enzymes required for complete plant-cell-wall hydrolysis? (4) Can the activity of cellulases and xylanases be improved by altering residues at the active site or within substrate-binding domains? (5) Can hybrid genes be designed which encode enzymes exhibiting increased activity against cellulose and hemicellulose? To investigate the last question Warren et al. (1987) constructed a gene encoding both EG and exoglucanase activities. The rationale of this approach is based on the synergism observed between endo- and exo-acting cellulases. If these complementary activities are expressed by a single polypeptide chain an increase in the synergism between the enzymes could be anticipated. However, hybrid enzyme did not exhibit improved cellulase activity. In contrast, a gene encoding only the CD of EG E from $C$. thermocellum exhibited a $400 \%$ increase in specific activity compared with the native enzyme; although, interestingly, the truncated enzyme had a decreased affinity for cellulosic substrates (Durrant et al. 1991). There are numerous other possibilities for constructing novel plant-cell-wall-degrading enzymes, and only future research will determine whether this approach will prove fruitful.

\section{GENETIC MANIPULATION OF ORGANISMS}

It can be visualized that the introduction of fibre-degrading enzymes into suitable gut micro-organisms will result in an improvement in the efficiency of plant-cell-wall utilization by ruminant and non-ruminant herbivores. The present review will discuss the possibility of improving plant-fibre degradation by genetic manipulation of rumen and silage bacteria, and also by the novel strategy of introducing cellulase genes into the germline of simple-stomached livestock. 
Rumen. The two major limitations in rumen fibre digestion are the rate and extent of plant-cell-wall hydrolysis. The total amount of cellulose and hemicellulose degraded in the rumen depends on the degree of lignification which in turn is related to the age of the crop (Demeyer, 1981). Is it reasonable to expect an increase in plant-fibre digestion in the rumen in response to increasing the activity or expression of cellulases and xylanases in rumen micro-organisms? Pretreatment of forage-based silages with cellulases resulted in an increase in solubility, and although the enzyme had no effect on the total degradability of plant cell walls, there was an increase in the rate of plant-fibre hydrolysis in the rumen (van der Meer \& van Es, 1987; Van Vuuren \& Spoelstra, 1987; Gomez Cabrera \& van der Meer, 1988). Thus, the introduction of genes encoding very active cellulases into key rumen bacteria may improve the rate, if not the extent, of cellulolysis. Such a genetic modification could reduce $\mathrm{N}$ loss which occurs when feeding ruminants silage-based diets, due to the imbalance of ammonia release and energy generated by metabolism of plant structural polysaccharides (Johnson, 1976). However, this presupposes that the rate of plant-cell-wall hydrolysis is limited by the activity of rumen cellulases and xylanases, rather than by the structure of plant fibre. Such an assumption is not proven. Russell \& Wilson (1988) have suggested that the introduction of cellulase and xylanase genes into rumen micro-organisms which predominate when ruminants are fed on cereal-based diets, could improve fibre digestion. The rationale for this proposal is that in cereal diets the predominant polysaccharide, starch, is rapidly fermented resulting in a decrease in rumen $\mathrm{pH}$ to below 6 . Under these more acidic conditions the rumen cellulolytic bacteria, $R$. albus, Ruminococcus flavefaciens, Fibrobacter succinogenes and Butyrivibrio fibrisolvens will not persist (Stewart, 1977; Russell \& Dombrowski, 1980) and, thus, fibre digestion will diminish (Ørskov \& Fraser, 1975). In view of the fact that cereal diets contain a considerable fibre component, and may be supplemented with $100-150 \mathrm{~g}$ forage $/ \mathrm{kg}$, the decrease in rumen $\mathrm{pH}$ will diminish the maximum utilization of structural carbohydrates contained in cereals. Russell \& Wilson (1988) argue that the introduction of a complete cellulolytic system into a rumen micro-organism, which grew in acid conditions, could improve fibre digestion when animals were fed on grain. A potential candidate for such a genetic alteration is Bacteroides ruminicola. The bacterium grows in acidic conditions, and will attach to food particles and express EG activity. The introduction of $\mathrm{CBH}$ and hemicellulase activities could potentially enable the organism to efficiently degrade plant cell walls.

How feasible is the genetic manipulation of rumen bacteria? Evidently, the first stage in such a process is the insertion of DNA into the selected organism. Teather (1985) has described the transfer of the broad host-range conjugative plasmid RP4 from $E$. coli to $B$. fibrisolvens. Furthermore, transformation and transfection of cells with phage DNA have been reported for Selenomonas ruminantium (Orpin et al. 1986a; Lockington et al. 1988). To achieve stable introduction of heterologous DNA into rumen bacteria requires the development of a stable vector system. It should be noted that cryptic plasmids have been described in $R$. albus, $R$. flavefaciens (Asmundson \& Kelly, 1987), B. fibrisolvens (Teather, 1982; Mann et al. 1986) and S. ruminantium (Orpin et al. 1986b; Martin \& Dean, 1989). Plasmids from the latter organism have been cloned into pUC-based vectors, and their mode of replication is being examined to assess their utility as cloning vectors (J. Murray and G. P. Hazlewood, unpublished results). The range of bacteria which can now be successfully transformed has been greatly extended by the use of 
electroporation (Luchansky et al. 1988), and it is likely that in the near future transformation systems for rumen bacteria, based on electroporation, will be developed.

The second stage in the genetic manipulation of rumen bacteria is to obtain efficient expression of heterologous genes. Several rumen bacterial genes encoding cellulases and other catabolic enzymes have now been cloned and in some cases sequenced (for example, see Gilbert \& Hall, 1987; McGavin et al. 1989; Ohmiya et al. 1989; Hazlewood et al. 1990; Poole et al. 1990). S1-mapping will delineate the regulatory sequences which could then be utilized in the efficient transcription and translation of foreign genes in rumen bacteria.

Having constructed the required genetically engineered rumen bacterium, the organism must be re-introduced into the rumen. This is likely to be the most problematic step in manipulating rumen function. Recent studies (Flint et al. 1989) have shown that $S$. ruminantium, but not Bacteroides multiacidus, could be re-established in the original ecosystem. In addition, an organism harbouring extra DNA (plasmid) may not be as competitive as the unmodified bacterium. This view is supported by Russell \& Wilson (1988) who showed a dramatic decrease in growth rate of $B$. ruminicola containing a heterologous erythromycin resistance $(\mathrm{Em})^{\mathrm{r}}$ plasmid. The introduced genetic trait was rapidly lost if selection pressure was not applied. Thus, the introduction of exogenous DNA must confer a clear selective advantage to the organism if the exogenous nucleic acid, and the genetically altered bacterium, are to persist in the rumen. It could be argued that functional cellulase genes will fufil this criterion. It should, of course, be pointed out that the use of antibiotic resistance genes as selectable markers, although widespread in laboratory experiments, would be totally inappropriate in the genetic manipulation of rumen micro-organisms.

Silage bacteria. The introduction of cellulolytic activity into Lactobacillus plantarum could also improve fibre digestion in ruminants. This organism, which is commonly inoculated onto freshly cut herbage during ensiling, ferments water-soluble carbohydrates (WSC) to predominantly lactic acid. The resultant low pH $(3 \cdot 6-4 \cdot 2)$ of the silage prevents the proliferation of deleterious anaerobes such as Clostridium sp., so that the preserved crop may be used primarily for winter feeding to ruminants. Although silage inoculants, consisting of $L$. plantarum, are widely used their effectiveness when WSC levels are low (wet summer) is limited, as insufficient substrate is available to generate the required lactic acid. The addition of plant-fibre-degrading enzymes could overcome the substrate limitation by releasing di- and monosaccharides from plant cell walls, which could then be fermented by $L$. plantarum to lactic acid.

Recent studies by several groups have demonstrated that the addition of polysaccharidases to ensiled herbage improves the rate of acid production, thus ensuring better-quality silage (Huhtanen et al. 1985; Jorgensen \& Cowan, 1989). Furthermore, the use of these enzymes also improves the rate of plant-fibre degradation and, thus, plant-cell-wall utilization in ruminants, probably by catalysing initial depolymerization of plant cell walls during ensiling. From the foregoing discussion it is apparent that the addition of cellulases and xylanases to ensiled herbage improves the efficiency of ruminant production. However, the cost of these enzymes prevents their extensive use. The introduction of cellulolytic-hemicellulolytic capacities into $L$. plantarum could provide a more cost effective method for applying these enzymes during ensiling.

The genetic manipulation of silage bacteria, such as $L$. plantarum, poses many of the problems encountered in the insertion of heterologous genes into rumen micro- 
organisms. Again, the first requirement is for a transformation system for the lactic acid bacterium. Recent studies (Luchansky et al. 1988; Bates et al. 1989; Scheirlinck et al. 1989) have described the insertion of various plasmids into $L$. plantarum by electroporation. Scheirlinck et al. (1989) recognized the importance of obtaining stable maintenance of foreign DNA in the absence of selection pressure. Subsequently, this group, using a vector which does not replicate in $L$. plantarum but contains a cloned segment of the organism's genomic DNA, integrated heterologous DNA into the genome of $L$. plantarum through homologous recombination. Such an approach requires a high transformation frequency, which is not generally available for $L$. plantarum strains (Bates, 1990). Rixon et al. (1990) have utilized an unstable L. plantarum plasmid to direct foreign DNA into the organism's chromosome, by growing lactobacilli containing the vector under non-selective conditions. Such an approach has wide applicability in $L$. plantarum strains, as there is no requirement for a high transformation frequency. Both Scheirlinck et al. (1989) and Rixon et al. (1990) have demonstrated that L. plantarum strains containing chromosomally integrated heterologous DNA maintain these foreign sequences in the absence of selection pressure, although amplification of the foreign genes does occur when selection pressure is applied. Furthermore, these integrated sequences do not affect the growth rate of the recombinant strains in monoculture or in silage ecosystems. Both groups have demonstrated that $C$. thermocellum endoglucanases (Bates et al. 1989; Scheirlinck et al. 1989) function in L. plantarum and the encoded enzymes are efficiently secreted by the lactic acid bacterium. Obviously, to achieve efficient plant-cell-wall hydrolysis requires the introduction of the full complement of enzymes which cleave cellulose and hemicellulose. In addition, an improvement in gene expression over that observed for the $C$. thermocellum genes is required. A potential approach for achieving the latter objective is to insert foreign genes into endogenous high-copy-number plasmids (300/cell) which are stably maintained in the absence of selection pressure. Several groups have described numerous cryptic plasmids in $L$. plantarum strains (West \& Warner, 1985) one of which has recently been sequenced (Bates \& Gilbert, 1989). The resultant findings showed that the plasmids belonged to the group of Gram positive extrachromosomal elements which replicate by the rolling circle mechanism. It is widely believed that these plasmids may be unsuitable for cloning vectors, as the insertion of heterologous DNA causes the plasmids to undergo severe DNA rearrangements.

When genetically manipulating organisms which are designed to inhabit open ecosystems, the question of gene transfer to indigenous micro-organisms must be considered. Because the frequency of genetic exchange must be minimized, it is desirable to incorporate heterologous DNA into the organism's genome in order to reduce the risk of horizontal transfer.

What are the realistic expectations of genetically manipulating rumen and silage bacteria? We believe the rumen organisms present a particularly challenging problem. Can we reasonably expect an organism which harbours exogenous DNA to compete in an energy-limited symbiotic environment? Will any change in fibre digestion achieved by modifying one organism, be buffered by a shift in the microbial population of the rumen to accommodate the introduced bacterium? In comparison, the silage ecosystem appears to be a relatively simple system. Silage inoculants are added at $10^{6}$ colony forming units/g forage. The organism will increase in mass 1000 -fold which is equivalent to ten generations over the first $48 \mathrm{~h}$ of ensiling. In addition, once the $\mathrm{pH}$ of the ensiled herbage 
starts to drop, due to proliferation of the Lactobacillus, the competing bacteria in the ecosystem will not multiply. Thus, the goal of using a genetically manipulated $L$. plantarum in the ensiling process appears to be more feasible than establishing an anaerobic organism, harbouring heterologous DNA, in the rumen.

\section{GENETIC MANIPULATION OF NON-RUMINANT LIVESTOCK}

The application of recombinant DNA technology to manipulate the germline of livestock provides us with the possibility of using transgenic techniques to manipulate the complement of enzymes secreted into the gastrointestinal (GI) tract of farm animals, with the object of improving nutrient utilization by simple-stomached animals. These animals depend on a consortium of cellulolytic and xylanolyric anaerobic bacteria, present in the hind-gut, to digest plant structural carbohydrates. Sugars released are fermented to volatile fatty acids (VFA) which are absorbed by the animal and utilized as $\mathrm{C}$ and energy sources. From the nutritional standpoint, hind-gut fermentation of sugars is inefficient because dietary energy and $\mathrm{C}$ are lost in the heat of fermentation and through methanogenesis. Furthermore, microbial biomass synthesized from dietary components in the hind-gut is lost to the animal. Finally, VFA, when absorbed, have only $60 \%$ of the energy value of an equivalent quantity of the monosaccharides from which they have been derived (Blaxter, 1962). From the foregoing discussion, it is apparent that substantially more energy would be available to non-ruminants, if plant structural carbohydrates could be digested in the small intestines and the sugars released absorbed without previous fermentation to VFA.

Existing barley-based diets for simple-stomached animals contain $\beta$-D-glucans and hemicellulose. Support for the notion that improved animal performance could result from introducing cellulases and xylanases into the GI tract of these animals is provided by Pettersson \& Åman $(1988,1989)$ and Hesselman \& $\AA$ man (1986), who showed increased performance of broiler chickens fed on cereal-based diets which were supplemented with $\beta$-1,4-glucanase.

To achieve the objective described previously requires that heterologous xylanase and cellulase genes are expressed in the exocrine pancreas and peptic cells, with the subsequent secretion of active enzymes in the GI tract. In this context. Swift et al. (1984) have shown that, in transgenic mice, the rat elastase gene is expressed specifically in the exocrine pancreas, and the enhancer sequence of this gene has been used to direct the expression of rat and human growth hormones in acinar cells of the pancreas (Swift $e t$ al. 1984). Furthermore, regulatory sequences of the chymotrypsin B gene will direct expression of reporter enzymes in exocrine pancreatic cell lines (Walker et al. 1983). Thus, appropriate enhancer sequences can be used to direct heterologous gene expression in the exocrine pancreas.

There have, to date, been no reports on the expression of cellulases and xylanases in transgenic animals, thus it must be established whether genes encoding these enzymes, when fused to the elastase enhancer and a polyadenylation sequence will be expressed exclusively in the pancreas. The role of introns in higher eukaryotic gene transcription is particularly pertinent to this question since prokaryotic genes lack introns. Using transgenic mice, Ornitz et al. (1985) showed that intervening sequences were essential for efficient expression of the rat growth hormone gene when controlled by elastase or metallothionin enhancers. However, the role of introns in prokaryotic gene expression in 
mammals remains to be elucidated. Secretion of active cellulase and xylanase in the GI tract is a prerequisite for effective digestion of plant fibre. The importance of signal peptides in transporting proteins across cell membranes is well established, but although their structure is similar in both eukaryotic and bacterial cells (Carne \& Sheele, 1984), it remains to be established whether the prokaryotic sequence will allow secretion of enzymes into the GI tract.

Recently, Hall et al. (1990) have shown that EG E from C. thermocellum is efficiently expressed and secreted in a mammalian cell line (Chinese hamster ovary) when fused to a prokaryotic or eukaryotic signal peptide. In addition, the enzyme was posttranslationally modified. presumably in the endoplasmic reticulum and golgi apparatus.

In addition to improving the utilization of existing diets, the genetic modification could provide the opportunity for increasing the proportion of forage and decreasing the cereal content of diets fed to simple-stomached animals. This would improve the efficiency of pig and poultry production, while freeing cereals for human consumption.

\section{REFERENCES}

Asmundson, R. V.\& Kelly, W. J. (1987). Isolation and characterisation of plasmid DNA from Ruminococcus. Current Microbiology' 16, 97-100.

Bates, E. E. M. (1990). The genetic manipulation of Lactobacillus plantarum. PhD Thesis. University of Newcastle.

Bates, E. E. M. \& Gilbert, H. J. (1989). Analysis of cryptic plasmid from Lactobacillus plantarum. Gene 85 , $253-258$.

Bates. E. E. M., Gilbert, H. J., Hazlewood, G. P., Huckle, J., Laurie, J. I. \& Mann, S. P. (1989). Expression of a Clostridium thermocellum endoglucanase gene in Lactobacillus plantarum. Applied and Environmental Microbiology 55, 2095-2097.

Bauchop, T. (1981). The anaerobic fungi in rumen fibre digestion. Agriculture and Environment 6, 339-348.

Béguin, P. (1990). Molecular biology of cellulose degradation. Annual Review of Microbiology 44, 219-248.

Béguin, P., Millet, J., Chauvaux. S. Yague, E., Tomme, P. \& Aubert, J.-P. (1989). In Enzyme Systems for Lignocellulose Degradation, pp. 57-72 [M. P. Loughlan, editor]. London and New York: Elsevier.

Bérenger. J.-F., Frixon, C., Bigliardi, J. \& Creuzet, N. (1985). Production. purification and properties of thermostable xylanase from Clostridium stercorarium. Canadian Journal of Microbiology' 31, 635-643.

Blaxter, K. L. (1962). The Energy Metabolism of Ruminants. London: Hutchinson.

Carne, T. \& Sheele, G. (1984). In The Secretory Process, pp. 256-284 [M. Cantin, editor]. London: Academic Press.

Chauvaux, S. Béguin, P., Aubert, J.-P.. Bhat, K. M., Gow, L. A., Wood, T. M. \& Bairoch, A. (1989). Calcium-binding affinity and calcium-enhanced activity of Clostridium thermocellum endoglucanase D. Biochemical Journal 265, 261-265.

Chen, C. M. . Gritzali, M. \& Stafford, D. W. (1987). Nucleotide sequence and deduced primary structure of cellobiohydrolase II from Trichoderma reesei. Bio/Technology 5, 274-278.

Creuzet, N., Bérenger, J.-F. \& Frixon, C. (1983). Characterization of exoglucanase and synergistic hydrolysis of cellulose in Clostridium stercorarium. FEMS Microbiology Letters 20, 347-350.

Dekker, R. F. H. (1985). In Biosynthesis and Biodegradation of Wood Components, pp. 505-533 [T. Higuchi, cdicor]. Orlando: Academic Press Inc.

Demeyer, D. I. (1981). Rumen microbes and digestion of plant cell walls. Agriculture and Environment 6, 295-337.

Deshpande, V., Lachke. A., Mishra, C., Keskar, S. \& Rao, M. (1986). Mode of action and properties of xylanase and $\beta$-xylosidase from Neurospora crassa. Biotechnology and Bioengineering 28, 1832-1838.

Durrant, A. J., Hall, J., Hazlewood, G. P. \& Gilbert, H. J. (1991). The non-catalytic C-tcrminal region of endoglucanase $E$ from Clostridium thermocellum contains a cellulose-binding domain. Biochemical Journal 273, 289-293

Eriksson, K.-E. \& Pettersson, B. (1982). Purification and partial characterization of two acidic proteases from the white-rot fungus Sporotrichum pulverulentum. European Journal of Biochemistry 124, 635-642. 
Ferreira, L. M. A., Durrant, A. J., Hall, J., Hazlewood, G. P. \& Gilbert, H. J. (1990). Spatial separation of protein domains is not necessary for catalytic activity or substrate binding in a xylanase. Biochemical Journal 269, 261-264.

Flint, H. J., Bisset, J. \& Webb, J. (1989). Use of antibiotic-resistance mutations to track strains of obligately anaerobic bacteria introduced into the rumen of sheep. Journal of Applied Bacteriology 67, 177-183.

Fukumori, F., Kudo, T., Sashihara, N., Nagata, Y., Ito, K. \& Horikoshi, K. (1989). The third cellulase of alkalophilic Bacillus sp. N-4: evolutionary relationship within the cel gene family. Gene 76, 289-298.

Fukumori, F., Sashihara, N., Kudo, T. \& Horikoshi, K. (1986). Nucleotide sequence of two cellulase genes from alkalophilic Bacillus sp. strain N-4 and their strong homology. Journal of Bacteriology 168, 479-485.

Ghangas, G. S. \& Wilson, D. B. (1988). Cloning of the Thermonospora fusca cellulase gene E2 in Streptomyces lividans: Affinity purification and functional domains of the cloned gene product. Applied and Environmental Microbiology 54, 2521-2526.

Gilbert, H. J. \& Hall, J. (1987). Molecular cloning of Streptococcus bovis lactose catabolic genes. Journal of General Microbiology 133, 2285-2293.

Gilbert, H. J., Hall, J., Hazlewood, G. P. \& Ferreira, L. M. A. (1990). The N-terminal region of an endoglucanase from Pseudomonas fluorescens subspecies cellulosa constitutes a cellulose binding domain which is distinct from the catalytic centre. Molecular Microbiology 4, 759-767.

Gilbert, H. J., Sullivan, D. A., Jenkins, G., Kellett, L. E., Minton, N. P. \& Hall, J. (1988). Molecular cloning of multiple xylanase genes from Pseudomonas fluorescens subspecies cellulosa. Journal of General Microbiology 134, 3239-3247.

Gilkes, N. R., Warren, R. A. J., Miller, R. C. Jr \& Kilburn, D. G. (1988). Precise excision of the cellulose binding domains from two Cellulomonas fimi cellulases by a homologous protease and the effect on catalysis. Journal of Biological Chemistry 263, 10401-10407.

Gomez Cabrera, A. \& van der Meer, J. M. (1988). Rate of degradation of organic matter and neutraldetergent in barley straw: effect of genetic variation and treatment with ammonia on degradation in sacco and in vitro. Netherlands Journal of Agricultural Science 36, 108-110.

Gorbacheva, I. V. \& Rodionova, N. A. (1977). Studies on xylan degrading enzymes. I. Purification and characterization of endo-1,4- $\beta$-xylanase from Aspergillus niger str.14. Biochimica et Biophysica Acta 484, 79-93.

Grépinet, O., Chebrou, M.-C. \& Béguin, P. (1988). Nucleotide sequence and deletion analysis of the xylanase gene $x y n Z$ of Clostridium thermocellum. Journal of Bacteriology 170, 4582-4588.

Hall, J. \& Gilbert, H. J. (1988). The nucleotide sequence of a carboxymethylcellulase gene from Pseudomonas fluorescens subsp. cellulosa. Molecular and General Genetics 213, 112-117.

Hall, J., Hazlewood, G. P., Barker, P. J. \& Gilbert, H. J. (1988). Conserved reiterated domains in Clostridium thermocellum endoglucanases are not essential for catalytic activity. Gene 69, 29-38.

Hall, J., Hazlewood, G. P., Huskisson, N. S., Durrant, A. J. \& Gilbert, H. J. (1989). Nucleotide sequence of a xylanase gene from Pseudomonas fluorescens subspecies cellulosa. Molecular Microbiology 3, 1211-1219.

Hall, J., Hazlewood, G. P., Surani, M. A., Hirst, B. H. \& Gilbert, H. J. (1990). Eukaryotic and prokaryotic signal peptides direct secretion of a bacterial endoglucanase by mammalian cells. Journal of Biological Chemistry 265, 19996-19999.

Hamamoto, T., Honda, H., Kudo, T. \& Horikoshi, K. (1987). Nucleotide sequence of the xylanase A gene of alkalophilic Bacillus sp. C-125. Agricultural Biological Chemistry 51, 953-955.

Hazlewood, G. P., Davidson, K., Laurie, J. I., Romaniec, M. P. M. \& Gilbert, H. J. (1990). Cloning and sequencing of the celA gene encoding endoglucanase A of Butyrivibrio fibrisolvens strain A46. Journal of General Microbiology 136, 2089-2097.

Hazlewood, G. P., Romaniec, M. P. M., Davidson, K., Grépinet, O., Béguin, P., Millet, J., Raynaud, O. \& Aubert, J.-P. (1988). A catalogue of Clostridium thermocellum endoglucanase, $\beta$-glucosidase and xylanase genes cloned in Escherichia coli. FEMS Microbiology Letters 51, 231-236.

Hesselman, K. \& Åman, P. (1986). The effect of $\beta$-glucanase on the utilization of starch and nitrogen by broiler chickens fed on barley of low or high viscosity. Animal Feed Science and Technology 15, 89-93.

Huhtanen, P., Hissa, K., Jaakkola, S. \& Poutianinen, E. (1985). Enzymes as silage additive. Effect on fermentation quality, digestibility in sheep, degradability in sacco and performance in growing cattle. Journal of Agricultural Science (Finland) 57, 284-292.

Johnson, R. R. (1976). Influence of carbohydrate solubility on non-protein nitrogen utilization in the ruminant. Journal of Animal Science 43, 184-191.

Jorgensen, O. B. \& Cowan, D. (1989). In Enzyme Systems for Lignocellulose Degradation, pp. 347-369 [M. P. Coughlan, editor]. London and New York: Elsevier Applied Science. 
Kellett, L. E., Poole, D. M., Ferreira, L. M. A., Durrant, A. J., Hazlewood, G. P. \& Gilbert, H. J. (1990). Xylanase B and an arabinofuranosidase from Pseudomonas fuorescens ssp. cellulosa contain identical cellulose-binding domains and are encoded by adjacent genes. Biochemical Journal 272, 369-376.

Knowles, J., Teeri, T. T., Lehtovaara, P., Penttila, M. \& Saloheimo, M. (1988). In Biochemistry and Genetics of Cellulose Degradation, pp. 153-169 [J.-P. Aubert, P. Béguin and J. Millet, editors]. London: Academic Press.

Lamed, R. \& Bayer, E. A. (1988). The Cellulosome of Clostridium thermocellum. Advances in Applied Microbiology 33, 1-46.

Lamed, R., Setter, E. \& Bayer, E. A. (1983). Characterization of a cellulose binding, cellulose-containing complex in Clostridium thermocellum. Journal of Bacteriology 156, 828-836.

Lee, S. F. \& Forsberg, C. W. (1987). Purification and characterization of an $\alpha$-L-arabinofuranosidase from Clostridium acetyobutylicum. Canadian Journal of Microbiology 33, 1011-1016.

Lockington, R. A., Attwood, G. T. \& Brooker, J. D. (1988). Isolation and characterization of a temperate bacteriophage from the ruminal anaerobe Selenomas ruminantium. Applied and Environmental Microbiology 54, 1575-1580.

Lowe, S. E., Theodorou, M. K., Trinci, A. P. J. \& Hespell, R. B. (1985). Growth of anaerobic rumen fungi on defined and semi-defined media lacking rumen fluid. Journal of General Microbiology 131, 2225-2229.

Luchansky, J. B., Muriana, P. M. \& Klaenhammer, T. R. (1988). Application of electroporation for transfer of plasmid DNA to Lactobacillus, Leuconostoc, Listeria, Pediococcus, Bacillus, Staphylococcus, Enterococcus and Propionibacterium. Molecular Microbiology 2, 637-646.

Lüthi, E., Love, D. R., McAnulty, J., Wallace, C., Caughey, P. A., Saul, D. \& Bergquist, P. L. (1990). Xylanase from the extremely thermophilic bacterium Caldocellum saccharolyticum: overexpression of the gene in Escherichia coli and characterization of the gene product. Applied and Environmental Microbiology 56, 1017-1024.

McGavin, M. J., Forsberg, C. W., Crosby, B., Bell, A. W., Dignard, D. \& Thomas, D. Y. (1989). Structure of the cel-3 gene from Fibrobacter succinogenes $\$ 85$ and characteristics of the encoded gene product, endoglucanase 3. Journal of Bacteriology 171, 5587-5595.

Mann, S. P., Hazlewood, G. P. \& Orpin, C. G. (1986). Characterization of a cryptic plasmid (pOM1) in Butyrivibrio fibrisolvens by restriction endonuclease analysis and its cloning in Escherichia coli. Current Microbiology 13, 17-22.

Martin, S. A. \& Dean, R. G. (1989). Characterization of a plasmid from the ruminal bacterium Selenomonas ruminantium. Applied and Environmental Microbiology 55, 3035-3038.

Ohmiya, K., Kajino, T., Kato, A. \& Shimizu, S. (1989). Structure of a Ruminococcus albus endo-1,4$\beta$-glucanase gene. Journal of Bacteriology 171, 6771-6775.

Ornitz, D. M., Palmiter, R. D., Hammer, R. E., Brinster, R. L., Swift, G. H. \& MacDonald, R. J. (1985). Specific expression of an elastase-human growth hormone fusion gene in pancreatic acinar cells in transgenic mice. Nature 313, 600-603.

Orpin, C. G. (1984). The role of ciliate protozoa and fungi in the rumen digestion of plant cell walls. Animal Science and Feed Technology 10, 121-143.

Orpin, C. G., Jordan, D. J., Hazlewood, G. P. \& Mann, S. P. (1986a). Plasmid profiles of the rumen bacteria Selenomonas ruminantium and Butyrivibrio fibrisolvens. Journal of Applied Bacteriology 61, xiv.

Orpin, C. G., Jordan, D. J., Mathiesen, S. D., Veal, N. J., Hazlewood, G. P. \& Mann, S. P. (1986b). Genetic transformation of the rumen bacterium Selenomonas ruminantium. Journal of Applied Bacteriology 61, xiii-xiv.

Ørskov, E. R. \& Fraser, C. (1975). The effects of processing of barley-based supplements on rumen pH, rate of digestion and voluntary intake of dried grass in sheep. British Journal of Nutrition 34, 493-500.

Paice, M. G., Bourbonnais, R., Destochers, M., Jurasek, L. \& Yaguchi, M. (1986). Two forms of endoglucanases from basidiomycete Schizophyllum commune and their relationship to other $\beta-1,4-$ glycoside hydrolases. Archives of Microbiology 144, 201-206.

Penttila, M., André, L., Saloheimo, M., Lehtovaara, P. \& Knowles, J. K. C. (1987). Expression of two Trichoderma reesei endoglucanases in the yeast Saccharomyces cerevisiae. Yeast 3, 175-186.

Penttila, M., Lehtovaara, P. \& Knowles, J. (1989). In Yeast Genetic Engineering, pp. 247-267 [P. J. Barr, A. J. Brake and P. Valenzuela, editors]. Stoneham, MA: Butterworth.

Penttila, M., Lehtovaara, P., Nevalainen, H., Bhikhabhai, R. \& Knowles, J. (1986). Homology between cellulase genes of Trichoderma reesei: complete nucleotide sequence of the endoglucanase 1 gene. Gene 45, 253-263. 
Pettersson, D. \& Àman, P. (1988). Effects of enzyme supplementation of diets based on wheat. rye or triticale on their productive value for broiler chickens. Animal Feed Science and Technology 20, 313-324.

Pettersson, D. \& Aman, P. (1989). Enzyme supplementation of a poultry diet containing rye and wheat. British Journal of Nutrition 62, 139-149.

Poole, D. M. Hazlewood, G. P., Laurie, J. I., Barker, P. J. \& Gilbert, H. J. (1990). Nucleotide sequence of the ruminococcus albus SY3 endoglucanase genes celA and celB. Molecular and General Genetics 223, $217-223$

Reilly, P. J. (1981). Xylanases: structure and function. Basic Life Sciences 18, 111-129.

Rixon, J. E., Hazlewood, G. P. \& Gilbert, H. J. (1991). Integration of an unstable plasmid into the chromosome of Lactobacillus plantarum. FEMS Microbiology Letters (In the Press).

Russell, J. B. \& Dombrowski, D. B. (1980). Effect of pH on the efficiency of growth by pure cultures of rumen bacteria in continuous culture. Applied and Environmental Microbiology 39, 604-610.

Russell, J. B. \& Wilson, D. B. (1988). Potential opportunities and problems for genetically altered rumen microorganisms. Journal of Nutrition 118, 271-279.

Saloheimo, M., Lehtovaara, P., Penttila, M., Teeri, T. T., Stahlberg, J., Johnsson, G., Pettersson, G., Claeyssens, M.. Tomme, P. \& Knowles, J. K. C. (1988). EGIII, a new endoglucanase from Trichoderma reesei: and the characterisation of both gene and enzyme. Gene 63, 11-21.

Scheirlinck, T., Mahillon, J., Joos, H., Dhaese, P. \& Michiels, F. (1989). Integration and expression of $\alpha$-amylase and endoglucanase genes in the Lactobacillus plantarum chromosome. Applied and Environmental Microbiology 55, 2130-2137.

Shoemaker, S., Schweickaert, V., Ladner, M., Gelfand, D., Kwok. S., Myambo, K. \& Innis. M. (1983). Molecular cloning of exo-cellobiohydrolase I derived from Trichoderma reesei strain L27. Bio/Technology 1, 691-696.

Sreenath, H. K. \& Joseph, R. (1982). Purification and properties of extracellular xylan hydrolases. Folia Microbiologica 27, 107-115.

Stewart, C. S. (1977). Factors affecting the cellulolytic activity of rumen contents. Applied and Environmental Microbiology 33, 497-502.

Swift, G. H., Hammer, R. E., MacDonald, R. J. \& Brinster, R. L. (1984). Tissue-specific expression of the rat pancreatic elastase 1 gene in transgenic mice. Cell 38, 639-646.

Takenishi, S. \& Tsujisaka, Y. (1973). Purification and some properties of three xylanases from Penicillium janthinellum. Journal of Fermentation Technology 51, 458-463.

Takenishi, S. \& Tsujisaka, Y. (1975). On the modes of action of three xylanases produced by a strain of Aspergillus niger. Agricultural Biological Chemistry 39, 2315-2323.

Teather, R. M. (1982). Isolation of plasmid DNA from Butyrivibrio fibrisolvens. Applied and Environmental Microbiology 43, 298-302.

Teather, R. M. (1985). Application of gene manipulation to rumen microflora. Canadian Journal of Animal Science 65, 563-574.

Teeri, T. T., Lehtovaara, P., Kauppinen, S., Salovuori, I. \& Knowles, J. (1987). Homologous domains in Trichoderma reesi cellulolytic enzymes: gene sequence and expression of cellobiohydrolase II. Gene 51 , 43-52.

Tomme, P., van Tilbeurgh, H., Pettersson, G., Van Damme, J., Vandckerckhove, J., Knowles, J., Tecri, T. \& Claeyssens, M. (1988). Studies of the cellulolytic system of Trichoderma reesei QM 9414. European Journal of Biochemistry 170, 575-581.

van der Meer, J. M. \& van Es, A. J. H. (1987). In Degradation of Lignocellulosics in Ruminants and in Industrial Processes, pp. 21-34 [J. M. van der Meer, B. A. Rijkens and M. P. Ferranti, editors]. Amsterdam: Elsevier Applied Science

van Tilbcurgh, H., Tommc, P., Claeyssens, M., Bhikhabhai, R. \& Pettersson, G. (1986). Limited proteolysis of the cellobiohydrolase I from Trichoderma reesei. FEBS Letters 204, 223-227.

van Vuuren, A. M. \& Spoelstra, S. F. (1987). Enzyme silage additives. In Stummary of Papers 8th Silage Conference, p. 109 [C. Thomas, editor]. Maidenhead: AFRC.

Walker, M. D., Edlund, T., Boulet, A. M. \& Rutter, W. J. (1983). Cell-specific expression controlled by the 5 'flanking region of insulin and chymotrypsin genes. Nature 306, 557-561.

Warren, R. A. J., Gerhard, B., Gilkes, N. R., Owolabi, J. B., Kilburn, D. G. \& Miller, R. C. (1987). A bifunctional exoglucanase-endoglucanase fusion protein. Gene 61, 421-427.

West, C. A. \& Warner, P. J. (1985). Plasmid profiles and transfer of plasmid-encoded antibiotic resistance in Lactobacillus plantarum. Applied and Environmental Microbiology 50, 1319-1321. 
Whistler, R. L. \& Richards, E. L. (1970). In The Carbohydrates - Chemistry and Biochemistry, 2nd ed., vol. 2A, pp. 447-469 [W. Pigman and D. Horton, editors]. New York: Academic Press Inc.

Wong, K. K. Y., Tan, L. U. L. \& Saddler, J. N. (1988). Multiplicity of $\beta-1,4$-xylanases in microorganisms: functions and applications. Microbiological Reviews 52, 305-317.

Wood, T. M. (1989). In Enzyme Systems for Lignocellulose Degradation, pp. 17-35 [M. P. Coughlan, editor]. London and New York: Elsevier Applied Science.

Wood, T. M., McCrae, S. I., Wilson, C. A., Bhat, K. M. \& Gow, L. A. (1988). In Biochemistry and Genetics of Cellulose Degradation, pp. 31-52 [J.-P. Aubert, P. Béguin and J. Millet, editors]. London: Academic Press.

Wu, J. H. D., Orme-Johnson, W. H. \& Demain, A. L. (1988). Two components of an extracellular protein aggregate of Clostridium thermocellum together degrade crystalline cellulose. Biochemistry 27, 1703-1709. 